\title{
Percutaneous transapical closure of cardiac apex and mitral prosthetic paravalvular leak is feasible and alternative approach to the septal approach
}

\author{
Cengiz Ozturk $^{1} \cdot$ Turgay Celik $^{1} \cdot$ Atila Iyisoy $^{1} \cdot$ Sevket Balta $^{1} \cdot$ Murat Tavlasoglu $^{2} \cdot$ \\ Mehmet Ali Sahin ${ }^{2} \cdot$ Adem Guler $^{2}$
}

Received: 20 April 2016/Accepted: 21 May 2016/Published online: 27 May 2016

(C) The Japanese Association for Thoracic Surgery 2016

\section{Dear Editor,}

We read the article entitled 'Transcatheter closure through transapical access for mitral paravalvular leak after previous trans-septal mitral operation' [1]. The authors noted that transapical approach for transcatheter paravalvular leak closure (PVLC) may an alternative technique for transcatheter paravalvular leak (PV) closure in the case of transseptal approach is not available, and they also reported that this is the first case report of transapical access for transcatheter PVC in Japan. There has been a growing interest in less invasive procedures, so catheter-based closure of a PV is a possible alternative to the surgical closure. A number of case series have been reported with encouraging success rates and good results [2-4].

There are new apical closure devices for closure of percutaneous apical accesses. We also reported previously two cases of successful percutaneous closure of the apical access with ADO-II devices after a standard transapical mitral PVLC procedure obtaining percutaneous puncture with a needle at the fifth intercostal space without minithoracotomy from Turkey [5, 6]. The conventional coronary angiogram (CAG) or computed tomography-guided CAG may be very useful to obtain optimal puncture of cardiac apex in order not to damage left anterior descending artery. The authors might

This comment refers to the article available at doi:10.1007/s11748016-0644-1.

\section{Cengiz Ozturk}

drcengizozturk@yahoo.com.tr

1 Department of Cardiology, Gulhane School of Medicine, Gulhane Military Medical Academy, Tevfik Saglam St., 06018 Etlik, Ankara, Turkey

2 Department of Cardiovascular Surgery, School of Medicine, Gulhane Military Medical Academy, Etlik, Ankara, Turkey consider percutaneous closure of the apical access with a device after a standard transapical mitral PVLC with a needle without minithoracotomy. Percutaneous apical closure of cardiac apex would be useful for the patients with high surgery risk as less invasive therapy.

Compliance with ethical standards

Conflict of interest There is no conflict of interest.

\section{References}

1. Murakami T, Suehiro Y, Nishimura S, Sugioka K, Iwata S, Ito A, Sohgawa E, Mizutani K, Yoshiyama M, Shibata T. Transcatheter closure through transapical access for mitral paravalvular leak after previous trans-septal mitral operation. Gen Thorac Cardiovasc Surg. 2016. doi:10.1007/s11748-016-0644-1.

2. Iyisoy A, Ozturk C, Celik T, Demirkol S, Tavlasoglu M, Sahin MA, Cingoz F, Demir M, Balta S, Unlu M. The combination of percutaneous transapical and transseptal closure of cardiac apex and prosthetic mitral paravalvular leak with loop technique. Int $\mathbf{J}$ Cardiol. 2015;203:221-4. doi:10.1016/j.ijcard.2015.10.132.

3. Ozturk C, Iyisoy A, Balta S, Celik T. Percutaneous transapical closure of cardiac apex and mitral prosthetic paravalvular leak is feasible and alternative approach to the surgery. Surg Curr Res. 2016;6:262. doi:10.4172/2161-1076.1000262.

4. Iyisoy A, Ozturk C, Tavlasoglu M, Sahin MA, Balta S, Celik T, Demirkol S, Unlu M, Arslan Z, Haqmal H. Significant left hemothorax after transapical closure of cardiac apex with minithoracotomy and transapical transcatheter prosthetic mitral paravalvular leak closure. Int J Cardiol. 2015;199:274-6. doi:10.1016/j.ijcard.2015.07.030.

5. Iyisoy A, Ozturk C, Celik T, Demirkol S, Cingoz F, Unlu M, Arslan Z. Percutaneous transapical closure of cardiac apex with an ADO-II device after successful transapical transcatheter prosthetic mitral paravalvular leak closure. Int. J. Cardiol. 2015;189:289-92. doi:10.1016/j.ijcard.2015.04.076.

6. Ozturk C, Iyisoy A, Celik T, Balta S, Bozlar U, Demir M, Yildirim AO, Guler A. Computed tomography guided percutaneous transapical closure of cardiac apex after prosthetic mitral paravalvular leak closure. Int. J. Cardiol. 2015;198:37-9. doi:10.1016/j.ijcard.2015.06. 121. 